\title{
Trickster or Colonizer: The Latent Effects of Colonialism in Efua Sutherland's Play The Marriage of Anansewa
}

\author{
J. Sunita Peacock \\ Slippery Rock University of Pennsylvania, Slippery Rock, PA, USA
}

\begin{abstract}
The essay analyzes the play written by the late Efua Sutherland (from Ghana) and shows the effects of colonization among the Ghanaians. First, it explores the historical inroads made by the colonizer in West African countries, such as Ghana, causing the debilitation of the culture of such countries by erasing its history. One way in which such erasure occurred was in the destruction of sacred sites of the people. Further connections will also be made to West African cultural contexts with the history of colonization in Africa and its effects on popular culture, specifically drama in countries like Ghana. Next, the essay draws upon the role of the trickster figure of Ananse, the spider who features in many West African and Caribbean folkloric traditions. Sutherland's play revolves around the main character of the play, Ananse, and he is likened to the trickster figure, but the essay shows how this figure is also debilitated by the colonizer. Finally, in the play, one notes that despite the main character's "victory" in getting his daughter married to the "Chief-Who-Is-Chief”, he does it for his survival and the survival of his daughter in a world in which the latent effects of colonization has hampered the memory and culture of its people.
\end{abstract}

Keywords: Africa, postcolonial, drama, folklore, history, literature

\section{Introduction}

Sutherland's play The Marriage of Anansewa has been acclaimed for it highlighting issues of "societal opportunism" and "contemporary social foibles” of Ghanaian society (Adams \& Sutherland-Addy, 2007, pp. 1-2). But in this essay, I am going to analyze and contemplate upon the latent effects of colonialism among the Ghanaian people as noted in the characters of Ananse and his daughter Anansewa in Sutherland's, The Marriage of Anansewa. The essay will explore, first, the historical inroads made by the colonizer for economic gain in areas of Western Africa, such as Ghana, and further show the erasure of sacred sites in such areas to understand how such erasures, in a microcosm, reveal the loss of memory and identity in the hearts and minds of the colonized people. Further, an exploration of colonialism within cultural contexts of West African popular culture will be noted to show its effects on popular culture, such as drama, which mirrors the social structure of African nations, specifically Ghana because of colonialism. To understand the connections created between colonialism and African indigenous works, the history of the trickster figure Ananse, a popular icon in West African and Caribbean folklore will be disseminated. Sutherland's main character, Ananse in The Marriage of Anansewa parallels the folkloric, spider-trickster figure of African yore. Again, through the examination of Ananse and his daughter Anansewa, the traditions of the Akan people that Sutherland is applauded for showing

J. Sunita Peacock, Associate professor, Ph.D., Department of English, Spotts World Culture, Slippery Rock University of Pennsylvania. 
in her plays will be revealed but the essay will also show how the specific postcolonial theory of a colonized nation's location (and in turn its people) oscillates between meanings as it complicates "the harmonious totalities of culture” (Spurlin, 2013, pp. 71-72) because of the colonial encounter.

\section{The Colonial Encounter in Efua Sutherland's The Marriage of Anansewa}

To fully understand the issues of location and the complications of one's culture and identity because of colonization, one needs to first examine the history of the colonial encounter between the colonizer and the colonized. In her study of the burial sites of the Ghanaian people, Greene in her book, Sacred Sites and the Colonial Encounter: A History of Meaning and Memory in Ghana, explores how Christian missionaries in Ghana blurred and sometimes even erased the borders between religion and culture among the people of Ghana in the area in and around the Gold Coast for over a period of 100 years (1850-1950). By evaluating the aspects of blurring and sometimes even erasing religious sites of the people along the Gold Coast, one can also argue how such opacity unwittingly affected the works of postcolonial writers and dramatists, such as Sutherland whose drama has been applauded for the uses of Ghanaian folk traditions to enhance modern dramatic works, as noted in The Marriage of Anansewa, which was published in 1987.

Further, an examination of the effects of colonialism on the social structures of African society also need to be mentioned to see how the colonizer affected the minds of the colonized people and in turn affected the social structures of popular culture, such as drama in the African context. In the book, West African Popular Theatre, by Barber, Collins, and Ricard, the authors note how the oral traditions (oriki chants, popular music-juju, and fuji) of West African nations from Ghana to Nigeria were re-introduced in "innovative and emblematic ways, incorporating colonial and post-independence” eras (Barber, Collins, \& Ricard, 1997, p. xii). The manner in which colonialism affected the oral traditions/music was the incorporation of the "text" (Barber, Collins, Ricard, 1997, p. xii). Other African elements that are present in the indigenous plays are the collaborative aspect of a performance with audience participation, and the "inclusion of a musical component and dance” (Barber, Collins, \& Ricard, 1997, p. xv). In Sutherland's play Marriage, one notes the colonial encounter of the use of "text" but also varied aspects of African drama "with the inclusion of a collaboration of characters who are outside the main action ( audience) music and dancing working in an egalitarian way on stage” (Barber, Collins, \& Ricard, 1997 intro xv). Later in the analysis of Sutherland's Marriage, one will note how the African dramatist retained aspects of society's oral tradition by using forms of improvisation in the "texts” (Barber, Collins, \& Ricard, 1997, p. xv).

Another effect of colonization along the Gold Coast (West African nations) was the emergence of a hybrid form in drama, depicting the hybrid identity of the colonized people. Because of the geography of the Gold coast and the importance of trade beginning from ancient times, the people of the area were familiar with foreign cultures. Hence, their own culture became "innovative and adept at social navigation to foster commercial networks; with this came an open and accommodating attitude toward foreign, imported cultural elements and a willingness to invest in entertainment” (Barber, Collins, \& Ricard, 1997, p. 1).

When the British colonizer entered West Africa, he imposed a commercial colonialism at the beginning of the nineteenth-century and with it came the creation of roads, railways, and an educational system, "which the colonial governments undertook to regulate” (Barber, Collins, \& Ricard, 1997, p. 2). As colonialism benefitted England/Europe, a new culture and new classes were created in Africa, beginning from "cash-cropping farmers" to an "intermediate class of traders, artisans, laborers etc....it was from the intermediate sector that modern 
West African popular culture emerged” (Barber, Collins, \& Ricard, 1997, p. 3). This hybrid culture will be noted later in Sutherland's Marriage.

Briefly, the plot of the play, Marriage is about a wily father Ananse who is in need of money to enhance his status in society and so he decides to marry his daughter to the chief who will pay him the largest sum of money for her hand. Ananse gets his daughter to type letters to four different chiefs, one of whom he hopes will offer the most money for his daughter. Ananse dictates what he wants his daughter to write in the letters and mails the letters to the chiefs with a photograph of his daughter in each of the letters. The prompt mailing of the letters and his daughter's photograph in each of them is done unbeknownst to Anansewa. The play begins with Ananse speaking to his daughter and reminding her that she needs to use her typing skills to help her father find a prospective groom for her as he spent money to send her to the E. P. Secretarial School and that he is not getting any younger and that he would need to live in comfortable surroundings in his old age. He emphasizes to her:

After you have gone out and returned home, here, will my hope for a more comfortable future be any better? The mattress on which I try to rest my bones after each day is up-and-down—will it have changed from a straw-stuffed, lumpy mattress to a soft, bouncy Dunlopillo[...]? Let alone some comfortable chairs to sit in? A fridge in the kitchen, a car in the garage? My name on invitation lists for state functions? Embassies’ parties? (Sutherland, 1987, p. 12).

To add insult to injury, Ananse laments, he does not even have enough money to put in the collection plate on Sundays in church!

Right from the beginning of the play one notes the history of imperialism in the lives of the people of Ghana, which has led playwrights, such as, Sutherland to unabashedly use the effect of colonization that is rampant in the lives of people of Ghana, hearkening to a hybrid identity: To note such an identity mirrored in plays, such as Marriage, a brief history of drama in Ghana needs to be revisited. In the formation of new classes being created by colonialism and the rise of an "intermediate class" of artisans, laborers, and traders, a modern, West African popular culture emerged (Barber, Collins, \& Ricard, 1997, p. 3). One important form of drama in West African popular culture was "the concert party, a contemporary, roving, comic opera-a dynamic folk art of Ghana” (Barber, Collins, \& Ricard, 1997, p. 6). This "slapstick musical comedy, with a strong seam of pathos and a very prominent moral tone” running through it was a common dramatic form (Barber, Collins, \& Ricard, 1997, pp. 6-7). In the early days of the concert party the colonial "vaudeville minstrelsy" was imported from Europe, but between the 1930s-1950s, "the genre became progressively Akanized" (People of Ghana referred to as the Akan people) "by the incorporation of an analogue of the Ananse-spider trickster character and the use of the Akan language” (Barber, Collins, \& Ricard, 1997, p. 7). Sutherland does just that with the protagonist, Ananse in Marriage. Continuing with the history of theatre in Ghanaian society, Barber also notes that by the 1960s-70s, the plays were "firmly planted in the everyday domestic world of contemporary Ghana, with salient references to cocoa, farms, banks, schools and the Ghana National lottery” (Barber, Collins, \& Ricard, 1997, p. 15). Sutherland was a director of the National Drama School in Ghana under Nkrumah and the school was financed by the government as The Marriage of Anansewa depicts exactly the themes, characters, and the colonized hybrid identity of the Ghanaian person and society. We see Marriage following "the core of the concert repertory" with the play "depicting" a family drama in "an exaggerated and amusing way” by showcasing contemporary problems of the audience” (Barber, Collins, \& Ricard, 1997, p. 23): Ananse has given his daughter an education and now he wants to marry her off to the richest suitor of his 
choice so that he can live a life of comfort (exaggeration about a father's materialist leanings), but the themes of the concert repertory are present with the dramatization of a father-daughter relationship with the daughter reacting unfavorably to the father's decision which Anansewa does when she notes that her father has sent her picture to several suitors without her permission.

Concurrently, the effects of colonization on society as depicted in popular culture can be further analyzed with both serious and contentious conclusions. First, the inroads that the colonizer made at the beginning of the nineteenth-century into the continent of Africa and especially in West Africa can be noted in Greene's book, which was mentioned earlier in the essay. The author shows how the people of the country whose culture is defamed react to such defamation. Greene uses the loss of burial sites of the Anlo people (who lived in and around the Gold Coast) by recalling the history of Christian missionaries in Ghana, between 1850 and 1890 . One important way of gaining the trust of the people whose land was being taken over by an outside force was by the outside force opening schools and hospitals for the people of the region. But by bringing "western technology and science education various water bodies lost their sacred aura and were rendered spiritually irrelevant” (Greene, 2002, p. 3). Greene continues, “According to dominant thinking in nineteenth-century Europe, the material world was quite separate from the spiritual world” (Greene, 2002, p. 3). Hence, when German missionaries came to Gold Coast communities, such as the Anlo, who lived in these areas and who put spiritual significance to physical sites, such as burial areas, "they were ridiculed, ignored, or selectively appropriated” by the western missionaries (Greene, 2002, p. 4). So, when burial sites of the Anlo people were destroyed by the colonizer, the colonized people "struggled in diverse ways and with differing degrees of success, to deploy, deform, and defuse" the cultural values and forms imposed upon them by the European missionary. Unfortunately, for the colonized individual, "his ability to choose what to accept and what to reject was circumscribed by the power dynamics embedded in the colonial enterprise" (Greene, 2002, p. 5). At any rate, for the colonized to survive and not to feel as though his entire culture/history was being erased, the life of the African, which was later embedded in literary forms (art, drama, and writing) had to continue and one way to make it work would be "through the traumatic encounter between Africa and Europe", as noted in Gikandi's essay African Literature and the Colonial Factor (Gikandi, 2007, p.54). In fact, according to Gikandi, the current hybridity in modern African literature is because of "the radical changes in society because of colonialism” (Gikandi, 2007, p. 55). These radical changes are noted when analyzing Sutherland's Marriage right from the start. The play is written in English (the language of the colonizer) and through her writing the dramatist is able to show the folk culture of Ghana (the use of the trickster, spider Ananse and other elements of the concert plays) along with the effects of colonization on the minds of the people of Ghana giving them a hybrid identity, which is viewed as a valid identity in modern Ghana in the twentieth and twenty-first centuries. Equally, Gikandi notes that with the arrival of the colonizer in the early nineteenth century, African writers wrote in European languages (Olaudah Equiano) "to oppose slavery and validate an African identity” (Gikandi, 2007, p. 55) and giving a voice and passage to the European world for the African writer (Gikandi, 2007, p. $55)$.

Paralleling Gikandi’s analysis of how the colonized adapted to the colonizer, Greene in Sacred Sites, gives an anthropological view of adaptation. Greene suggests how individual memory

situates what (they-the Anlo people of the Gold Coast) recollect within the mental spaces provided by the group. These mental spaces are composed of ideas (how one thinks about past experiences) language (how one speaks of what one remembers) and places (material sites that support our mental images). (Greene, 2002, pp. 8-9) 
Just like the Anlo people, on the Gold Coast, who are representative of many communities in Ghana that were affected by colonization through the destruction of an important Ghanaian practice of house burials over the creation of public cemeteries, so also in the play Marriage, one sees an adaptation of burial/funeral rites. In response to the colonizer's removal of certain physical sacred sites, the Anlo people diffused their culture by embracing the "new meanings that the colonial encounter had begun to encourage them to accept about sites of historical significance" (Greene, 2002, p. 8), and "These new meanings gradually gave rise to new collective memories and the bodily practices that supported them” (Greene, 2002, pp. 8-9).

Paralleling the Anlo people's forced adaptation of their own culture is Ananse's adaptation of thinking about certain customs of his village. In Act Three of the play, Ananse's aged mother is angry with her son because he has chosen to have an "outdooring ceremony" for his daughter Anansewa, "five years after the girl has become a woman, which is not good custom keeping in anyone's world..." His mother continues, "Your school people say you have thrown these things aside” (Sutherland, 1987, p. 44). Ananse's mother's lament mirrors the "new meanings" that Greene discusses earlier when the Anlo people lost their sacred sites. To combat loss, the Anlo form "new collective memories". Hence, erasing their former memories of whom and what they were and instead creating a new hybrid identity. Ananse's mother's lament in Marriage parallels the Anlo people's change of memory in the character of Ananse who mirrors a similar change because of the effect of colonization and the erasure of memory summoned by "schooling" imposed upon the colonized by the colonizer. Historically, the African had no choice as Gikandi notes that after the conference of Berlin of 1885, "the whole continent was divided among European powers" (Gikandi, 2007, 55). African societies either had to “adapt or perish” (Gikandi, 2007, p. 56).

On the one hand, the character of Ananse has a loss of memory of his culture because of his need for a fridge, a fan, and funds for church; thus embracing the colonial ideal of western materialism. But on the other hand, Sutherland also gives her universal audience Ghanaian culture adapting its past to its decolonized present. Then again, with issues raised by authors, such as Greene and the loss of burial sites and certain important African traditions, the narrative of colonialism can be "conceived as the unwilled evacuation of African subjects” from their history (Greene, 2002, p. 56).

What Sutherland gives both Ghanaian and universal audiences are a colonial event that was merely an interruption in African society (Greene, 2002, p. 56). Historically, early African nationalist writers opposed imperialist rule and fought for African political rights. But what

this meant was that African literature was not initially intended to provide a radical critique of European rule; rather, it was a discursive mode through which Africans could try to represent and mediate their location both inside and outside colonial culture. (Greene, 2002, p. 57)

In Sutherland's character, Ananse we see him moving inside and outside African and European culture. For example, he feels that to be comfortable in his old age, he needs western accoutrements such as, a fridge, a car, and money to put in the church's collection plate, at the expense of his daughter's marriage to the chief who is the highest bidder. The fridge, car, and the Christian church juxtapose with Ananse arranging a marriage between his daughter and chiefs from different villages. His "schooling”, as his mother laments, has him changing the time of his daughter's "outdooring ceremony". But Ananse does not change everything in his culture, instead, he weaves in and out of it because of his hybrid identity created by the influence of the imperialist. Ananse's idea of success and comfort come from the importation of the culture of the colonizer as 
it coincides with his Ghanaian culture.

Sutherland's treatment of burial lore is with humor. The scene, toward the end of the play when Ananse realizes that all four chiefs have paid well for his daughter and they are all coming for her hand in marriage becomes a moment of concern for the conniving father. When Ananse hears that all the chiefs are coming for his daughter's hand in marriage, he prepares for a mock funeral for his daughter. In Act Four, the Storyteller within the play notes Ananse starts drilling his daughter. Anansewa is pretending dead? "very well. It turned out that he did his work well” (Sutherland, 1987 p. 69). Ananse's dilemma of who to give his daughter's hand to, as all chiefs have paid him the bride price, and more, is solved. As news of the arrival of the four chiefs reaches Ananse's ears, he instructs his daughter to "stiffen your limbs" (Sutherland, 1987, p. 55), to act like she is dead. Anansewa laughingly replies, "but I have never died before” and again Ananse tells her to "hold her breath, a little," and Anansewa replies, "How can I switch my life off and on like electricity” (Sutherland, 1987, p. 55). In this exchange between father and daughter, Sutherland satirizes burial law and "home burials" that Greene describes in her exploration of how the German colonizers destroyed the cultural norms of the Anlo/Ghanaian people to suit their purpose of imperialist takeover and in this humorous example Sutherland is using death/burial as an instrument of "resistance against colonization" (Gikandi, 2007, p. 58). One can conjecture, though, that Sutherland's satire informs the audience how the colonizer has destroyed certain cultural norms of a society but by the same token how the colonized is able to adapt and change his identity by locating himself inside and outside the colonial way of thinking. In Sutherland's play, the humor stems from the fact that death/burial is used to trick the chiefs and the trickster Ananse is successful. Herein lies the movement of the colonized inside and outside his hybrid identity.

As noted earlier in the essay, West African dramatic forms went through many changes because of the advent of colonization. A distinctive theatre tradition that emerged was an inclusion of indigenous African traditions (dances, symbols, audience participation, singing etc.) and most importantly, "the impact of the cycle of tales associated with the trickster figure of Ananse the spider” (Gibbs, 2004, p. 160).

In analyzing the trickster figure of the spider who is the "folk hero of Ghanaian and Caribbean folk tales", Deandrea notes, in the article titled Trans (l) Atlantic I-con: The Many Shapes of Ananse in Contemporary Literatures, that, "tricksters" in all oral literatures cause "laughter and profane nearly every central belief, but at the same time they focus attention precisely on the nature of such beliefs" (Deandrea, 2004, p. 2).What Sutherland creates in The Marriage of Anansewa in the protagonist Ananse is taking the folklore of the spider/trickster stories of the Akan people and "reduce" them to writing in a text. In his essay, "Ghana”, Gibbs (2004) uses the word "reduce" to claim that it is an appropriate term because the process of reduction "involved stripping them (the tales) of the gestures and the musical elements that flesh out the performance and dramatists have reversed the process" (Gibbs, 2004, p. 160). What Sutherland did was to "transform the tales (anansesem) into plays (anansegro)” (Gibbs, 2004, p. 160). In fact in her foreword to the play Marriage, Sutherland notes, that the storytelling art called "anansesem" by the Akan-speaking people has been transformed by her into "anansegoro" using "some of the conventions of anansesem to reveal the bases of The Marriage of Anansewa" (Sutherland, 1987, p. 3).

In Sutherland's Marriage, the father Ananse arouses laughter and at times tends to, as Deandrea (2004) notes, profanes, and focuses attention on certain cultural beliefs (which is the role of the trickster). As noted by his mother, he disregards the actual time period of his daughter's outdooring ceremony conducting it right before she is to be married. So, he profanes the belief but the audience's attention is drawn to the belief by his 
casual use of it. By the same token, Ananse's disregard leads to chaos in his life, but then again he manages to pull off certain schemes that could cause disasters and regain normalcy once again, without him being found out. According to Pelton in The Trickster in West Africa, (2004) the figure of Ananse can also be interpreted as "a way to unveil the ethical and religious principles of Akan society”. By Ananse's attack on certain important principles in his culture, he is able to "regenerate them creatively, under modified shapes" (Deandrea, 2004 p. 2). Inevitably, though, Ghanaian novelist Ayi K. Armah shows Ananse in an utterly negative model of selfishness to suggest that "Ghanaian society is dominated by an Anansean rush for material acquisition", which can also be analyzed as a side effect of colonization (Deandrea, 2004, p. 4).

It is true that in Marriage, the character of Ananse does have a sense of insolence as measured by the way in which the critic Pelton (2004) describes the spider/trickster figure. He is ready and willing to misuse the customs of marriage/outdooring/burial ceremonies, which is seen throughout the play, possibly, for the dramatist to reveal through the use of Ananse, the use of "domestic activity" (Sutherland, 1987, p. 3) that are in existence in Ghanaian society but they are "given full theatrical expression" through the exaggerated character of the spider/trickster figure and the changes established by the latent effects of colonialism on Ghanaian domesticity (Sutherland, 1987, p. 3).

Ananse is bold as he asks four chiefs to marry his daughter hoping that only one will comply; he totally disregards his daughter's feelings toward marriage and although he sends her to typing school to learn a skill, he uses her skills to suit his own purposes, one of them being using her for marriage to a rich chief to eventually put large sums of the money he receives in the collection plate during church service in his village to gain personal recognition. Hence, the trickster figure serves a dual purpose as he not only reminds the audience of the tales of the African's past, but also the effect of materialism and colonialism on the African's future.

Next, according to Adams and Esi Sutherland-Addy (2007), in their introduction to the book titled The Legacy of Efua Sutherland: Pan African Cultural Activism, Sutherland's play Marriage, brings to the forefront "contemporary societal foibles as can be seen in the practices of local Christian churches, the chicanery of artisans, and the desperation of societal opportunists” (Adams \& Esi Sutherland-Addy, 2007, p. 2). The contemporary themes used in the play hearken back to Barber's mention of Ghanaian plays being "firmly planted in the everyday domestic world of contemporary Ghana” (Adams \& Esi Sutherland-Addy, 2007, p.15).

The effect of colonization and its existence within traditional African culture is depicted further in the trickster figure, Ananse's use of traditional African customs of arranging a marriage for his daughter so that he can purchase a fridge and have money to put in the collection plate at his local church, shows, in my estimation, Sutherland's humorous dig of the destructive nature of colonial materialism embedded in the African psyche. But then again, with the happy ending in Marriage with Anansewa getting a chief who cares about her needs and also supplies the needs of her father, declares the notion of the African being able to locate himself/herself inside and outside of the colonial culture (Gikandi, 2007, p. 56). The implementation of the trickster figure, could also symbolically show the manner in which the colonizer tricked the colonized into believing amongst several things that the African did not "have a history, philosophy or language prior to the Europeans" (Gikandi, 2007, p.56). This idea of chicanery is noted in one particular scene when Ananse, as stage directions note, is behind a "web screen" (Sutherland, 1987, p. 53). In this same scene, his daughter enters, singing and joyous because of her outdooring ceremony and the fact that she is now a woman ready to be married: "We have touched your lips with an egg to bless you, and we have dressed you in gold to honor you" says Anansewa as she mimes her ceremony (Sutherland, 1987, p. 53). Ananse's figure behind the web is symbolic of the 
spider/trickster who has trapped his prey in his web of deceit as his daughter Anansewa is unaware of her father's reasoning for wanting to marry her off to the highest bidder. Once again, colonial philosophy is at the heart of literary/dramatic traditions and conveys a close association in African literature (Gikandi, 2007).

Ananse's role playing as noted in the spider/trickster figure could further symbolize a country in flux whose inhabitants have shifting identities because of colonization. One part of the character of Ananse is to, according to Perce's (1968) article, The Didactic Essence of Efua Sutherland's Plays, "outwit all around him” because of his need for a comfortable life in his old age; the other reason according to Pearce, could be to protect his daughter and himself in a difficult world, "especially when they are pitted against the more privileged class represented by the wealthy chiefs” (Pearce, 1968, p. 80). This disparity between two groups of people in the society in which Ananse resides could hearken back to colonization when societies that were colonized by an outside power lost, according to Bhabha, "the harmonious totalities of culture” (Spurlin, 2013, p. 72). The purity of the colonized domain is lost and such nations call into question their cultural practices which are "relegated to the outside of constitutive nationhood allowing for gaps, the collapse of certainty, and the evocation of the erasure of borders to come into play, and opening up the possibility of new narratives of the nation” (Spurlin, 2013, p. 79). In paralleling Bhabha's theory of the gaps in the identities of the people of colonized nations, one can surmise the actions of tricksters like Ananse who emerge to possibly widen such gaps by outwitting their own people.

Sutherland has been hailed as one of Ghana's leading directors of experimental theater groups beginning in 1950 and bringing into focus, according to Pearce, the rituals of Ghanaian society. Her inclusion of several narrative schemes taken from oral African tradition, costumes, props, folkloric trickster figures (Ananse), dance, and music combined with the influx of colonial discourse (writing in the language of the colonizer and the effects of colonization on the main character, Ananse), she is able to give us insights into the psyche of the decolonized African person who moves inside and outside the colonial encounter

According to Brown (1981) in the book, Women Writers in Black Africa, Sutherland sees a connection between the art of theater (writing, producing, acting) and traditions within a culture (Brown, 1981, p. 61). Hence, "Sutherland's theater is symbolic of Ghanaian culture as a whole insofar as that culture exemplifies the interaction of Western and African values" (Brown, 1981, p. 62). It is true that in Marriage Sutherland takes the traditional Ghanaian idea of marriage into which she infuses the effects of westernization on such a tradition. And as the title, of the play suggests, it is the marriage of Anansewa, which is about a woman who is central to the action of the play; thereby, "using the conventions of the theater" as a "symptom of the manner in which social conventions-in this case Ghana's-have blended new and old values, non-African (colonial) and African traditions” (Brown, 1981, p. 63).

\section{Conclusion}

To conclude, many social conventions from Ghanaian folklore are used in the play, such as the father (Ananse) arranging the marriage for his daughter (Anansewa) to the chief of his choice; one also notes the father's choice of postponing the outdooring ceremony of his daughter till he is ready to give her hand in marriage, and the father being in charge of the women in the household, such as his mother and his daughter. Within the dramatic structure of the play, Marriage, one also notes features of folk tradition with the use of singing by a group of women who weave in and out of the actions in the play and who act as a chorus while important events occur within the drama; there is a Storyteller who comes and gives background information 
throughout the play; the main characters, such as Ananse, orders a backstage hand referred to as the Property Man to bring props on and off the stage. All of this is a part of Ghanaian dramatic folk tradition, which Sutherland juxtaposes with comments from the main characters that show the influence of westernization, such as the desire for western goods by the main character, Ananse. As mentioned earlier, the effects of colonization is also noted throughout the analysis of Marriage and the new evolution of Ghanaian traditions in Sutherland's transformation of the art of story-telling (anansesem) into textual dramatic forms.

\section{References}

Adams, A., \& Esi Sutherland-Addy, V. (2007). The legacy of Efua Sutherland: Pan African cultural activism (pp. 1-26). Oxfordshire: Ayeba Clarke Publishing, Ltd..

Barber, K., Collins, J., \& Ricard, A. (1997). West African popular theatre. Bloomington: Indiana University Press.

Brown, L. W. (1981). Women writers in Black Africa. Westport: Greenwood Press.

Deandrea, P. (2004). Trans(l)atlantic i-con: The many shapes of Ananse in contemporary literatures. Journal of Transatlantic Studies, 2(1), 1-26.

Gibbs, J. (2004). Ghana. In M.Banham, (Ed.), A history of theatre in Africa (pp.159-170). New York: Cambridge University Press.

Gikandi, S. (2007). African literature and the colonial factor. In T. Olaniyan \& A. Quayson, (Eds.), African Literature: An anthology of criticism and theory (pp.55-59). Oxford: Blackwell Publishing.

Greene, S. E. (2002). Sacred sites and the colonial encounter: A history of meaning and memory in Ghana. Bloomington: Indiana University Press.

Pelton, R. (1989). The trickster in West Africa: A study of mythic irony and sacred delight. Los Angeles: University of California Press.

Pierce, A. (1968). The didactic essence of Efua Sutherland's plays. Women in African Literature Today, 71-80.

Rotimi, O. (2007). The attainment of discovery: Efua Sutherland and the evolution of modern African drama. In A. Adams, \& V. Esi Sutherland-Addy (Eds.), The legacy of Efua Sutherland: Pan african cultural activism (pp.18-23). Oxfordshire: Ayeba Clarke Publishing, Ltd.

Spurlin, W. T. ( 2013). Shifting geo-political borders/Shifting sexual borders; Textual and cultural renegotiations of national identity and sexual dissidence in postcolonial Africa. Studies in Ethnicity and Nationalism, 13, 69-79.

Sutherland, E. T. (1987). The marriage of Anansewa. United Kingdom: Longman African Classics. 